\title{
Cutting Tool Wear Monitoring
}

Jan Madl, Michal Martinovsky

Faculty of Production Technology and Management, J. E. Purkyne University in Usti nad Labem, Pasteurova 3334/7, 400 01, Usti nad Labem, Czech Republic. E-mail: madl@fvtm.ujep.cz, martinovsky@fvtm.ujep.cz.

Cutting tool wear monitoring is one of key problems in automation of machining processes. Apart from the cutting tool wear monitoring for the cutting tool change and cutting tool failure, cutting tool wear monitoring may be one of the components for the adaptive control of a machining process. This paper is focused on the design of turning cutting tool wear sensors of the system flap - jet principal with increased extend. On the geometric principles in cutting with a turning cutting tool, the relations among the output of jet mouth, clearance angle and cutting tool wear were expressed. Two variants of turning cutting tool sensors were designed and experimentally verified. The results of experiments have proved the possibility to apply cutting tool wear sensor of the system flap - jet principal with increased extend in practical use.

Keywords: Machining, Cutting tool wear, Monitoring.

\section{Acknowledgement}

The paper was supported by Internal grant of SGS at the University of Jan Evangelista Purkyne in Usti nad Labem within specific university research.

\section{References}

[1] MARK, A. (2000). Insert has built-in wear sensor. Modern Machine Shop. Vol. 73, No. 5, p. 1.

[2] CAROLAN, T. A., KIDD, S. R., HAND, D. P., WILCOX, S. et al. (1997). Acoustic emission monitoring of tool wear during the face milling of steels and aluminium alloys using a fiber optic sensor. Proceedings of the Institution of Mechanical Engineers. Vol. 211, No. 4, p. 11.

[3] ZIZKA, J. (2003). Pouziti akusticke emise ke sledovani stavu rezneho nastroje. Liberec: TU Liberec. p. 106. ISBN 80-7083-687-1.

[4] GOMES DE OLIVEIRA, J. F., DORNFELD, D. A., Winter, B. (1994). Dimensional Characterisation of Grinding Wheel Surface through Acoustic Emission. Annals of the CIRP. Vol. 1, p. 291.

[5] KOCMAN, K., PROKOP, J. (2001). Prediction of Grinding Wheel Parameters. Manufacturing Technology. Vol. 1, No. 1, pp. 26-32.

[6] TONSHOFF, T., FREIMUTH, J. C., BECKER, R. (2002). Process Monitoring in Grinding. Annals of the CIRP. Vol. 2, pp. 551-671.

[7] SHIBATA, J., GOTO, T., YAMAMOTO, M., TSUWA, H. (1982). Characteristics of Air Flow Around a Grinding Wheel and their Availability for Assessing the Wheel Wear. Annals of the CIRP. Vol. 1, p. 233.

[8] BRINKSMEIER, F. (1992). Monitoring of Grinding Wheel Wear. Annals of the CIRP. Vol. 1, p. 373.

[9] BI, X. F., YANG, C. Sc. (2013). Research on Crater Wear Monitoring. Applied Mechanics and Materials. Vol. 436-442, pp. 2390-2393.

[10] DIEI, E. N., DORNFELD, D. A. (1987). Acoustic emission from the face milling process-the effects of process variables. Trans. ASME. Vol. 109, pp. 234-240.

[11] MADL, J. Tool Wear and Breakage Monitoring in Machining (1992). VDI Berichte, Nr. 94, pp. 274-250.

[12] GIUST, D., SANTOCH, M., TANTUSSI, G. (1987). On Line Sensing of Flank Wear and Crater Wear of Cutting Tools. Annals of the CIRP. Vol. 1, p. 41.

[13] HRABOVSKY, T., NesluSan, M., MiCieta, B., CillikovA, M., MiCietovAl, A. (2014). Berkhausen Noise Emission of Surfaces Produced by Hard Milling Process. Manufacturing Technology. Vol. 14, No. 1.

[14] MICUCH, M., CILLIKOVA, M., NESLUSAN, M., MICETOVA, A. (2014). Influence of Cutting Conditions and Grinding Wheel Wear on Bergausen Noise of Ground Surfaces. Manufacturing Technology. Vol. 14, No.1.

[15] CASENSKY, M. (1970). Meridlo s rozsirenym rozsahem. Prague: CVUT in Prague, K235, CTU. [Research Report].

[16] NGUYEN, V. G. (1975). Vysokotlaka pneumaticka meridla. Prague: CVUT. Doctoral thesis. CVUT in Prague, K234, CTU. 